\title{
Media Portrayal on Global Climate Change: an Analysis of Malaysian Mainstream Newspapers
}

\author{
Nor Jijidiana Azmi ${ }^{1}$, Nor Azikin Mohd Omar ${ }^{1}$, Safawati Basirah Mohd Zaid ${ }^{1}$, Zanirah Wahab ${ }^{1}$, Akmah Yusof ${ }^{1}$ \\ ${ }^{1}$ Faculty of Language and Communication, Universiti Sultan Zainal Abidin, Terengganu, Malaysia \\ Correspondence: Nor Jijidiana Azmi, Faculty of Language and Communication, Universiti Sultan ZainalAbidin, \\ Terengganu, Malaysia
}

Received: December 8, 2014

Accepted: January 26, 2015 Online Published: May 11, 2015

doi:10.11114/smc.v3i1.815

URL: http://dx.doi.org/10.11114/smc.v3i1.815

\begin{abstract}
The global climate change can affect human life and activities through the increasing amount of natural disasters, global warming and the melting of the icebergs. This study was conducted to analyze the Malaysian media's coverage of global climate change in four Malaysian mainstream newspapers. The data for this study were collected for two years, beginning January 2008 to December 2010. A content analysis was conducted to identify the frequency of the articles related with global climate change and the trend of newspaper coverage and the frames of the articles. The findings for this study will provide an understanding about the ways Malaysian mainstream newspapers provide the coverage about global climate change and the public's reactions. The findings also revealed that the coverage was influenced by other global events when the trend of newspaper coverage shows a dramatic surge in coverage during important events related to global climate change.
\end{abstract}

Keywords: newspaper, climate change, content analysis, newspaper coverage, Malaysian newspaper

\section{Introduction}

In today's society, a majority of the public utilize the media to gain information on current events, local and international news, and even celebrity gossip. This is because the public does not have direct access to news that exists outside of their immediate surroundings, hence the media plays a vital role to educate the public on many other important issues. One important issue is the global climate change. Wilson (1995), in his study, stated that a majority of the public rely on the media to obtain information on global climate change. His study shows that the media is not only a tool for delivering local and international news, but it has also become a major source of information to the public. Previous studies also revealed that newspaper coverage on global climate change had increased over the years to parallel the public's desire to know about this ever increasing problem that has affected their lives (Zehr, 2000, Doulton \& Brown, 2009, Sampei \& Aoyagi-Usui, 2009).

Presently, the global climate change has become an important concern for all countries, including Malaysia. Malaysia, a developing country with a 27 million population, is located in Southeast Asia. Like other neighboring countries, such as Singapore and Indonesia, Malaysia is rapidly developing. It is not surprising, therefore, that Malaysia was ranked number 26 among the world's largest carbon emitters in 2008 (insert year if you have it).

Boykoff and Roberts (2007) asserted that all humans contribute to climate change in various ways, but not many realize that human activities are one of the major contributors to global climate change. Calvaho and Burgess (2005) suggest that media practitioners should play a role by framing such news development by constructing the news accordingly based on careful examination and observation. Framing the global climate change news appropriately is therefore a crucial matter for media practitioners. Careful framing of the news will allow the public to have a better understanding and awareness on the global climate change issue that affects the world at large (Boykoff \& Roberts, 2007).

\subsection{Problem Statement}

The world has undergone many devastating global climate change effects such as the occurrence of natural disasters, the rise of diseases, water shortage, and food crisis amongst others (Lewis \& Boyce, 2000). As such, there is increased worldwide media coverage on global climate change over the past few decades because of its high news value. This is especially true of media coverage in the United States, the United Kingdom, Japan and Mexico in 2009, the year that 
saw high media coverage of climate change around the world (Boykoff, 2010).

Japan is among the countries with the highest newspaper coverage on global climate change since 2007 onwards (Sampei\& Aoyagi-Usui, 2009). This increased amount of newspaper coverage in the country has been beneficial to the country when it increased public awareness on global climate change issue in Japan (Sampei \& Aoyagi-Usui, 2009), therefore changing the mindset of the Japanese people.

Regrettably, Malaysia lacks newspaper coverage on global climate change. No earlier study was found on this issue in the Malaysian context, and therefore it is important that a study of this nature is conducted so that the trend of newspaper coverage can be identified. This will create a better understanding on the issue.

A pilot study was first conducted on this issue from January 3 to January 9, 2011. Findings revealed that the issue of global climate change in Malaysia has not received much media attention. Through the pilot observation, the researcher recorded the number of articles and features on global climate change in four Malaysian mainstream newspapers:BeritaHarian, Utusan Malaysia, New Straits Times and The Star. The purpose of this observation was to record how frequent global climate change issue appeared in the newspapers. Within the period, only two stories on global climate change appeared in the Malaysian mainstream newspapers: an article in the Malay-language BeritaHarian entitled 'KesedaranKitarSemula Kita TidakSetandingWargaJepun' (Malaysians Lack Awareness on Recycling Compared to the Japanese) waspublished on January 3, 2011; and an article in the New Straits Times entitled 'Changing Climates' appeared on January 8, 2011.

The purpose of this research is to identify the trend, frequency and frame on global climate change news in Malaysia mainstream newspapers in order that accurate information on the trend can be identified.

\subsection{Significance of Research}

This research has several significances; the first is to help the public understand the importance of Malaysian mainstream newspapers in covering global climate change issues. This is because the media coverage reveals the newspapers' concerns and attention to the issue and it will also serve as an impetus for the public to have more concerns and awareness. Furthermore, this research can provide the scholars and the public with information on the frames utilized in Malaysia mainstream newspapers coverage. This is important so that a better understanding of the way the newspapers conveys news to the public are highlighted.

\section{Methodology}

The methodology used in this research is content analysis, a research technique that identifies specific characteristic in a text so that inferences can be drawn (Krippendorf, 2004). To make inferences, a careful examination of the data like text, audio or visual of any human interaction in the radio, television commercial, newspaper, films or novels needs to be carried out (Neuendorf, 2002). To identify the specific characteristic within the text, a few steps and procedures need to be followed. The content analysis used in this study allows the researcher to count the number of words of each article in the newspapers, identify the themes of the articles, and consequently allows the researcher to identify the emerging pattern of Malaysian newspapers coverage on the issue of global climate change.

\subsection{Sample}

The samples for this research are derived from articles inBeritaHarian and Utusan Malaysia, two of the most influential Malay-language newspapers, and The Star and the New Straits Times, two leading English-language newspapers. The articles in the newspapers on global climate change were retrieved from BERNAMA Infolink Service (BLIS) using English-language and Malay-language keywords search like pemanasan global or global warming, perubahaniklimor climate change.

\subsection{Coding Procedure and Pilot Test}

For this research, the researcher utilized the inductive approach of content analysis. The inductive approach of content analysis requires the researcher to conduct an open coding process to identify the themes of the raw materials on global climate change. This is achieved by a thorough reading of each of the retrieved articles and features. After completion, the themes and frames were identified using paragraph by paragraph coding. Table 1 provides the list of frames and themes identified in the articles. Twelve themes were identified and were categorized into three major frames.

Only two coders were used for this research: the researcher, who is the primary coder, and a second coder, who is literate in both English and Malay. Limiting it to two coders for this research makes it easier for the researcher to monitor and gain cooperation with one another that also helps to obtain valid and credible results.

A pilot test on the coding scheme was then conducted so that it can reveal whether the coding scheme is reliable or unreliable. To ensure the reliability of the coding scheme, the intercoder reliability results must fall between .75 to .80 (Neuendorf, 2002). However, Frey, Botan and Kreps (2000) (as cited in Neuendorf, 2002), asserts that a 70\% agreement 
is also acceptable and reliable.

First, a percentage agreement (PAo) was calculated. The result of the percentage agreement is PAo=.81 $(81.0 \%$ Agreement). After the percentage agreement was calculated, the intercoder reliability for the pilot test was calculated using Scott's $p i$ formula. As the number of data in the pilot study was small,the researcher did a manual count of the percentage. The formula is presented in Appendix 4. The result of Scott's $p i$ for the pilot test falls on .773 or $77.3 \%$.

Because the results have exceeded the minimum requirement, it indicates that the coding scheme is valid and meaningful. The researcher then proceeded with the coding process for other newspapers stories and features on global climate change. The remaining 517 articles and features were distributed accordingly between the two coders. The analysis was then carried out after the coders completed the coding process.

\section{Results}

This section provides the findings of the analyzed data on global climate change that has appeared in four Malaysian mainstream newspapers. The frequencies of articles and the frame of the articles were analyzed. Table 1 represents the frequency. It is important to identify the frequencies of newspapers coverage on global climate change because it reflects the media's concerns with the issue.

\subsection{Frequency of Newspaper Coverage in Malaysia Mainstream Newspaper}

The frequencies of the newspaper article are important to identify the amount of attention given by the newspapers on global climate change. The frequency of newspaper coverage is an indication of whether the issue is important to the newspaper or otherwise. It also becomes an indicator of the newspapers' concerns. The more articles there are on global climate change, the more it indicates that the newspapers are concerned and are making concerted efforts at providing their audience with information on the issue.

Table 1. Articles on Global Climate Change Published in Malaysia Mainstream Newspapers from 2008 to 2010

\begin{tabular}{|c|c|c|c|}
\hline Newspapers & $\begin{array}{ll}\begin{array}{l}\text { Number } \\
\text { (Frequency) }\end{array} & \text { of } \\
\end{array}$ & Articles & $\begin{array}{l}\text { Percentage } \\
(\%)\end{array}$ \\
\hline New Straits Times & 243 & & 42 \\
\hline Utusan Malaysia & 116 & & 20 \\
\hline BeritaHarian & 82 & & 14 \\
\hline The Star & 134 & & 24 \\
\hline Total & 575 & & 100 \\
\hline
\end{tabular}

In total, the coverage of global climate change in four Malaysian mainstream newspapers from January 2008 to December 2010 is 575 units of articles. Table 4.1 shows the quantity of articles of newspapers coverage by Malaysian mainstream newspapers, whilst Figure 4.1 represents the percentage of coverage by each newspaper.

From the result, both the English-language newspapers, the New Straits Times and The Star, have the most articles on global climate change. The New Straits Times has the highest total numbers of articles on global climate change with 243 units of article from January 2008 to December 2010. Meanwhile, The Star has the second highest total numbers of articles on global climate change from the same period which is $24 \%(\mathrm{n}=134)$ of the total article on global climate change from four Malaysia mainstream newspapers.

Utusan Malaysia had only 20\% ( $\mathrm{n}=116)$ coverage on global climate change in the same period. Whilst the least amount of newspaper coverage on global climate change article is BeritaHarianwith $14 \%(\mathrm{n}=82)$ of coverage of global climate change issue compared to the other Malaysian mainstream newspapers.

Hence, from the data, it is clear that the English daily, The New Straits Times, produced the highest amount of articles pertaining to global climate change from January 2008 to December 2010. On the other hand, The Star and the Malay daily newspaper, Utusan Malaysia, have an average amount of coverage and contributed a fairly similar amount of coverage on global climate change. The number of articles produced by these two newspapers is slightly different. A conclusion can be made that both The Star and Utusan Malaysia have an average level of concern on the issue of global climate change.

\subsection{Trend of Newspaper Coverage in Malaysian Mainstream Newspaper}

Figure 1 represents the trend of newspaper coverage on global climate change in four Malaysian mainstream newspapers in a span of two years. Findings show that there is a steady increase in the coverage from the beginning to the end of the study period, especially in The Star newspaper. Other newspapers, on the other hand, show a steady rise and fall trend of newspaper coverage. 


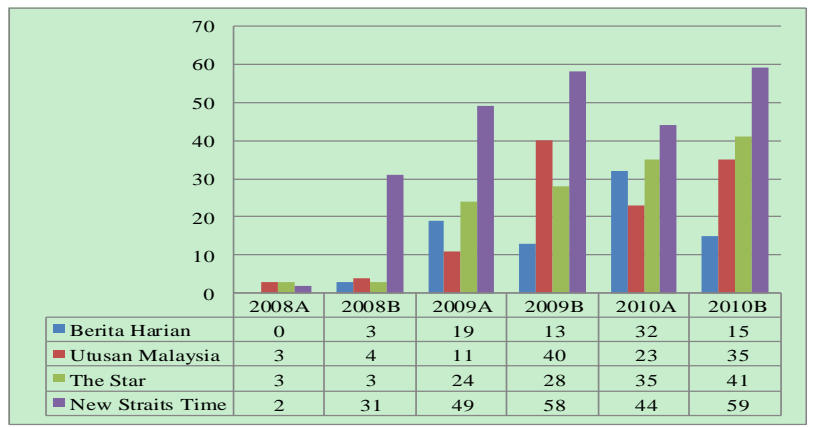

Figure 1. Trend of Newspapers Coverage on Global Climate Change from 2008 to 2010

*2008A indicate the first half of year 2008 (January to June) while 2008B indicate the second half of year 2008 (July to December), etc.

The four Malaysian mainstream newspapers are the New Straits Times, The Star, Utusan Malaysia and BeritaHarian. In Figure 1, the columns labeled Year 2008(a), 2009(a) and 2010(a) indicated the first half of the years, which is January until June. Meanwhile, 2008 (b), 2009 (b) and 2010(b) indicate the second half of year 2008, 2009 and 2010, which is in July until December.

\subsubsection{Peak in Malaysian Newspaper Coverage on Global Climate Change}

The months with increased coverage of global climate change in Malaysian mainstream newspapers were January 2009 to June 2009, July 2009 to December 2009, and July 2010 to December 2010. In Malaysia, this growing attention on global climate change reveals that the newspapers are becoming more aware of the issue despite the diverse degree of attention given. This scenario shows a positive trend in the coverage of global climate change in Malaysian mainstream newspapers.

As for the trend, the first peak coverage was from January 2009 to June 2009, which was due to the many occurrences on global climate change in that period. For example, in March 2009, Malaysia participated in the World Wide Fund (WWF) campaign on global climate change that is Earth Hour. As this was Malaysia's first participation in the Earth Hour Campaign, the Malaysian media, including the newspapers, gave nationwide coverage and increased their coverage on the campaign. This period also saw many newspaper articles linking the global climate change to the Earth Hour Campaign and Earth Day in April. It was also a means to inform the public about the campaigns whilst educating and influencing the public to participate in a campaign that first began in Sydney, Australia on March 31, 2007 (WWF, 2011).

The second peak of coverage on the global climate change wason July 2009 to December 2009. This can be attributed to many domestic and international interrelated events on global climate change. The three important events were the launch of Malaysia Green Technology Policy on July 24, 2009, Commonwealth Heads of Government Meeting (CHOGM) 2009, held on November 27, 2009 to November 29, 2009, and the 2009 United Nations Climate Change Conference that was held in Copenhagen, Denmark on December 7 to December 18, 2009.

The growing attention on environmental issues, particularly on the global climate change, was also evident when the Malaysian government adapted the climate change policy in 2009. This triggered an increased coverage on global climate change in the second half of 2009 where it was revealed that Malaysia produced 187 million tonnes of carbon dioxide (Bernama, 2009), an alarming figure in and of itself. This situation went on to become eye opening to the public, the government, the NGOs and environmentalists who began to formulate plans to reduce the emissions of greenhouse gas. As a result, the Malaysian government took the initiative to combat the problem by developing the country's policy on climate change programme which was launched on July 24, 2009 by the Prime Minister of Malaysia, Dato' Seri NajibTunRazak. The Malaysia Green Technology Policy promoted low-carbon technology that enables a reduction of the country's carbon footprint.

In addition, in July 2009 to December 2009, the coverage increased because of the impending United Nation Climate Change Summit in Copenhagen, Denmark, which was to be held in December 2009. The summit received participations from many countries including the United States of America, China, India, Japan, the United Kingdom, Indonesia and Malaysia. The aim of the summit was to stabilize the greenhouse gas emission in the atmosphere to a level that will not bring harm to the climate (Dell'Amor, 2009).

Based on the newspapers coverage, the public learnt that the delegates who came to the conference from many countries weretheir effort at showing their concern towards global climate change. The summit was important because it was also the final meeting of the world government before a renewal of climate change agreement that replaces Kyoto Protocol took place (Copenhagen 2009, 2009). The summit also attracted worldwide media coverage, including Malaysia, 
because of the U.S. President Barrack Obama's participation. His participation indicated the importance of the conference to the public at large.

The third peak of global climate change coverage in Malaysian's mainstream newspapers was in July 2010 to December 2010. This is due to the 2010 United Nations Climate Change Conference in Cancun, Mexico, which was held from November 29 to December 10, 2010.

As a conclusion, the trend of the newspapers' coverage on global climate change in Malaysia mainstream newspapers does descriptively correlate with the major events related to the issue. Therefore, this provides the answer to the second objective of this study, which is to identify the trend of newspapers coverage of Malaysian mainstream newspapers article on global climate change issue. To reiterate, the trend is descriptively correlated with the occurrences of events pertaining to the issue where the amount of newspaper coverage increased during occasions related to global climate change. This supports a previous study by Newig (2004) that the coverage of certain issues is influenced by certain trends and patterns that grab the public's attention. Therefore, it is not surprising that the newspapers coverage on global climate change issue had drastically increased during major events and would consequently decrease when there is no major occasion related to global climate change.

\section{Conclusion}

The media is an important tool to convey messages to a large audience because the public rely on the media to obtain many different types of information on world issues and events. Without the media, the public would not be able to access local and international news. The media also has the ability to influence public opinion and change public consciousness, making it a powerful tool that can persuade the public into taking actions.

This study is conducted as an effort to understand how much the global climate change issues are covered in the Malaysian mainstream newspapers by identifying the frequency and trends. The newspaper is a significant and effective medium that the public generally trusts to convey news and information. Setting an agenda in the newspaper helps the public to focus on relevant, timely and important issues. McCombs and Shaw (1977) stated that in order to set the agenda effectively for the public, the media needs to recognize that the public needs to face some level of orientation. The level of orientation is important in order to ensure the effectiveness of agenda setting theory, which is to influence the audience and make the audience think and act accordingly.

The issue presented in this study, which is the global climate change, has become one of the most significant event in the world because of its calamitous effects. Scientists, environmentalists, and politicians have different perspectives and opinions on the matter, and it is the media who needs to select suitable information from the experts for public dissemination. Previous studies were conducted on the significant correlation between global climate change and media coverage (see Sampei\& Aoyagi-Usui, 2009; Sonnet, 2009; Boykoff, 2010; Gavin et al., 2010; Gordon et al., 2010; Takahashi, 2010; Arlt et al., 2011; Miah et al., 2011) which led them to believe that related events to the global climate change is descriptively correlated with the media coverage. Sampei and Aoyagi Usui (2009) also pointed out that the increasing media coverage on global climate change issue had also increased public awareness on the subject. The same can be said of the findings from this research in that public awareness increased through the media coverage.

This research has a few implications. One implication is that it can shed light on the trend of Malaysian mainstream newspaper coverage on global climate change in the Malaysian context. This may be useful especially to the media as it can help them to increase the newspaper coverage on global climate change issue when necessary. Furthermore, this research can serve as a reference point for future researchers to conduct a research on broader topics of newspaper coverage within the scope of the global climate change in the Malaysian context.

To conclude, the findings from this research reveal a positive trend and improvement in newspapers' coverage on global climate change. However, it is recommended that the newspapers focus on specific themes such as the cause of global climate change so that a more detailed and comprehensive information is relayed to the public to trigger awareness, increase their knowledge and necessitate action.

\section{Acknowledgment}

This research is conducted through the cooperation of all the co-authors and the proofreader. I would like to express my gratitude to everyone who had made their contributions and showed support during this research.

Our deepest gratitude also goes to Universiti Sultan ZainalAbidin for providing the fund to conduct this research.

\section{References}

Antilla, L. (2005). Climate of Scepticism: US Newspaper Coverage of theScience of Climate Change.Global Environmental Change, 15. http://dx.doi.org/10.1016/j.gloenvcha.2005.08.003

Arlt, D., Hoppe, I., \& Wolling, J. (2011). Climate change and media Usage: Effects on Problem Awareness and 
Behavioral Attention.International Communication Gazette, 73(45). http://dx.doi.org/10.1177/1748048510386741

Billet, S. (2009). Dividing Climate Change: Global Warming in the IndianMass Media. Climatic Change, 99, 1-16. http://dx.doi.org/10.1007/s10584-009-9605-3

Boyce, T., \& Lewis, J. (eds.) (2009). Climate Change and the Media. New York: Peter Lang Publishing Inc.

Boykoff, M. (2010). Indian Media Representations of Climate Change in a Threatened Journalistic Ecosystem. Climatic Change 99.

Boykoff, M. T. (2008). The Cultural Politics of Climate Change discourse in UK Tabloids. Political Geography, 27(5). http://dx.doi.org/10.1016/j.polgeo.2008.05.002

Boykoff, M. T., \& Boykoff, J. M. (2005). Climate Change and Journalistic Norms: ACase-Study of US mass-media coverage. Retrieve on $3^{\text {rd }}$ September 2010 from www.sciencedirect.com.

Boykoff, M. T., \& Roberts, J. T. (2007). Media Coverage of Climate Change: Current Trends, Strenghts and Weaknesses. Retrieve on $30^{\text {th }}$ August 2010 from http://hdr.undp.org

Doulton, H., \& Brown, K. (2009). Ten Years to Prevent Catastrophe? Discourse of Climate Change in and International Development in the UK Press. Global Environmental Change, 19. http://dx.doi.org/10.1016/j.gloenvcha.2008.10.004

Gavin, N. T. (2010). Pressure Group Direct Action on Climate Change: The Role of the Media and the Web in Britain-A Case Study. The British Journal of Politics and International Relation, 12 http://dx.doi.org/10.1111/j.1467-856X.2010.00411.x

Gavin, N. T., Leonard, M. L. \& Montgomery, J. (2011). Climate Change, Flooding and the Media in Britain. Public Understanding of Science, 20(422). http://dx.doi.org/10.1177/0963662509353377

Gordon, J. C., Deines, T., \& Havice, J. (2010). Global Warming Coverage in the Media: Trends in a Mexico City Newspaper. Science Communication, 32(2). http://dx.doi.org/10.1177/1075547009340336

Griffin, E. (2003). A First Look at Communication Theory. New York: Mc-Graw Hill.

Krippendorff, K. (2004). Content Analysis: An Introduction to Its Methodology. California: SAGE Publication.

Miah, M. D., Kabir, M. H., Koike, M., \& Akhter, S. (2011). Major Climate ChangeIssue Covered by the Daily Newspapers of Bangladesh. Environmentalist. http://dx.doi.org/10.1007/s10669-010-9305-6

Neuendorf, K. A. (2002). The content Analysis Guidebook. California: SAGE Publication.

Sampei, Y., \& Aoyagi, U. M. (2008). Mass-media Coverage, its influence on Public Awareness of Climate Change Issues, and Implications for Japan's National Campaign to Reduce Greenhouse Gas Emissions. Global Environmental Change, 19.

Sonnet, J. (2010). Climates of Risk: A Field Analysis of Global Climate Change in US Media Discourse, $1997-2004$. Public Understanding of Science, 19, 698. http://dx.doi.org/10.1177/0963662509346368

Takahashi, B. (2011). Framing and Sources: A Study of Mass Media Coverage of Climate Change in Peru during the V ALCUE. Public Understanding of Science, 20, 543. http://dx.doi.org/10.1177/0963662509356502

The Climate Change Performance Index. (2008). A Comparison of Emission Trends and Climate Protection Policies of Top 56 CO2 Emitting Nations. Retrieved from http://www.germanwatch.org/klima/ccpi2008.htm

The Climate Change Performance Index. (2011). Result 2011. Retrieved from http://www.germanwatch.org/klima/ccpi2011.htm

Zehr, S. (2000). Public Representation of Scientific Uncertainty about Global Climate Change. Public Understanding of Science, 9. http://dx.doi.org/10.1088/0963-6625/9/2/301

\section{(cc) BY}

This work is licensed under a Creative Commons Attribution 3.0 License. 